\title{
Kinerja Usaha Budidaya Ikan Lele (Clarias sp.) di Kelompok Tani Lele "Mutiara" Desa Kaligelang, Taman, Pemalang
}

\author{
[The Performance of Catfish Farming (Clarias. sp.) in the "Mutiara" Catfish \\ Farmers Group, Kaligelang Village, Taman, Pemalang]
}

Ani Lutfiyanah, lin Siti Djunaidah

\author{
Program Studi Penyuluhan Perikanan, Politeknik Ahli Usaha Perikanan \\ Jalan Cikaret No 2 Bogor Selatan, Kota Bogor 16132
}

\begin{abstract}
Abstrak
Penelitian ini dilakukan di Kelompok Tani Lele "Mutiara" Desa Kaligelang, Kecamatan Taman, Kabupaten Pemalang dengan tujuan untuk mengetahui sistem produksi dan untuk menganalisis kelayakan usaha budidaya ikan lele. Penelitian ini dilaksanakan melalui magang pada tanggal 12 September 2020 sampai dengan 11 Oktober 2020. Data dianalisis secara deskrptif kualitatif dan kuantitatif. Berdasarkan hasil penelitian, diketahui bahwa pada sistem produksi budidaya ikan lele terdapat beberapa tahap yaitu persiapan kolam, penebaran benih, pemberian pakan, pemeliharaan ikan, pengendalian hama dan penyakit, hingga tahap pemanenan. Dalam usaha budidaya ikan lele dengan menggunakan teknologi bioflok, dalam satu siklus pada kolam berukuran $8 \mathrm{~m}^{2}$ rata-rata jumlah produksi mencapai $825 \mathrm{~kg}$ dengan SR 92,5\% dan produktivitas kolam 102,9 kg.m-2. Budidaya ikan lele khususnya pembesaran ini layak dijadikan usaha dengan indikator kelayakan usaha yaitu $B E P=33,5 \mathrm{~kg}, \mathrm{PP}=1,4$ tahun, $\mathrm{ROI}=53,37 \%$, dan $\mathrm{R} / \mathrm{C}=1,53$. Pendapatan yang diperoleh yaitu sebesar Rp.17.100.000 dengan keuntungan Rp. 5.951.094 dan biaya produksi Rp. 11.148.906 per siklus.
\end{abstract}

Kata kunci: bioflok; kelayakan usaha; lele

\section{Abstract}

This research was conducted at the "Mutiara" Catfish Farmers Group, located in Kaligelang Village, Taman District, Pemalang Regency with the aim to analyze the production system and to the financial feasibility of catfish farming. This research was carried out through an apprenticeship from 12 September 2020 to 11 October 2020. The results showed that the catfish farming production system, namely there were several stages from pond preparation, seed distribution, feeding, fish maintenance, pest and disease control, to harvesting stage. In the catfish farming business using bioflock technology, in one cycle in a pond measuring $8 \mathrm{~m}^{2}$ the average amount of production reaches $825 \mathrm{~kg}$ with a SR of $92.5 \%$ and a pond productivity of $102.9 \mathrm{~kg} \cdot \mathrm{m}^{-2}$. Catfish cultivation, especially this enlargement, is feasible to be a business with indicators of business feasibility, namely $\mathrm{BEP}=33.5 \mathrm{~kg}, \mathrm{PP}=1.4$ years, $\mathrm{ROI}=53.37 \%$, and $\mathrm{R} / \mathrm{C}=1.53$. The income obtained is Rp. $17,100,000$ with a profit of Rp. 5,951,094 and production costs of Rp. 11,148,906 per cycle.

Key words: bioflock; catfish; feasibility

\section{Penulis Korepondensi}

Ani Lutfiyanah | anilutfi02@gmail.com 


\section{PENDAHULUAN}

\section{Latar Belakang}

Provinsi Jawa Tengah merupakan penghasil ikan lele (Clarias sp.) terbesar kedua di Indonesia. Sentra budidaya ikan lele (Clarias sp.) di provinsi ini tersebar di beberapa kabupaten, salah satunya di Kabupaten Pemalang. Kabupaten Pemalang memiliki potensi di bidang perikanan, khususnya budidaya dengan produksi ikan mencapai 13.815 ton dengan didukung luas tambak 1.728 ha dan luas kolam air tawar 28,52 ha (BPS 2016). Berdasarkan kondisi alam dan potensi yang ada, kawasan budidaya perikanan di Desa Kaligelang, Kecamatan Taman ditetapkan sebagai Kampung Lele dan menjadi sentra pembesaran ikan lele (Clarias sp.). Jumlah produksi ikan lele (Clarias sp.) di Desa Kaligelang, Kecamatan Taman adalah kurang lebih 180 ton (Anon 2020).

Produksi ikan lele (Clarias sp.) setiap tahunnya selalu mengalami kenaikan. Pada tahun 2015 produksi ikan lele mencapai 719.619 ton per tahun dan pada tahun 2016 meningkat menjadi 764.797 ton per tahun. Pada tahun 2017 produksi lele nasional sebesar 1.771 .867 ton meningkat $131,7 \%$ dari tahun sebelumnya (DJPB, 2018). Oleh karena itu, ikan lele (Clarias sp.) sangat diminati masyarakat dan merupakan komoditas yang paling banyak dibudidayakan di semua provinsi di Indonesia, termasuk Jawa Tengah.

Kelompok Tani Lele "Mutiara" merupakan kelompok usaha budidaya dan pemasaran ikan lele yang sedang berkembang. Selain itu, Kelompok Tani Lele "Mutiara" merupakan salah satu kelompok yang menjadi perhatian dan memperoleh bantuan dari Dinas Kelautan dan Perikanan Kabupaten Pemalang, dan Kementerian Kelautan Perikanan. Kelompok ini mendapat bantuan berupa induk ikan lele (Clarias sp.), pakan, alat pembuat pakan, terpal, dan teknologi bioflok. Hal ini menjadi dasar dilakukannya penelitian di Kelompok Tani Lele "Mutiara".

\section{Tujuan}

Tujuan dari penelitian ini adalah:

1. Mengetahui sistem produksi budidaya ikan lele di Kelompok Tani Lele "Mutiara" di Desa Kaligelang, Kecamatan Taman, Kabupaten Pemalang, Jawa Tengah.

2. Menganalisis kelayakan usaha budidaya ikan lele di Kelompok Tani Lele "Mutiara" di Desa Kaligelang, Kecamatan Taman, Kabupaten Pemalang, Jawa Tengah.

\section{METODE PENELITIAN}

Metode yang digunakan pada penelitian ini adalah observer as participant yaitu mengikuti semua kegiatan yang di 
laksanakan untuk memperoleh data dan informasi dari hasil wawancara, observasi, diskusi, terkait sistem produksi dan kelayakan usaha budidaya ikan lele secara detail.

\section{Waktu dan Lokasi Penelitian}

Penelitian ini dilaksanakan pada tanggal 12 September 2020 sampai dengan 11 Oktober 2020. Penelitian bertempat di Kelompok Tani Lele "Mutiara" di Desa Kaligelang, Kecamatan Taman, Kabupaten Pemalang, Jawa Tengah

\section{Jenis dan Sumber Data}

Jenis data yang dikumpulkan terbagi menjadi data primer dan data sekunder. Data primer merupakan data yang diperoleh dari kegiatan yang dilakukan dengan pengamatan (observasi). Observasi dilakukan terhadap berbagai kegiatan yang bersangkutan dengan sistem produksi budidaya ikan lele. Data sekunder merupakan data yang diperoleh dari studi pustaka, laporan yang diperoleh dari lembaga penelitian swasta atau masyarakat yang berhubungan dengan sistem produksi dan kelayakan usaha budidaya ikan lele.

\section{Metode Pengumpulan Data}

Pengumpulan data dilakukan dengan tiga teknik yaitu observasi secara langsung, wawancara, dan dokumentasi. Observasi merupakan salah satu teknik pengumpulan data yang dilakukan dengan mengamati langsung, melihat dan mengumpulkan data suatu data yang dibutuhkan. Sedangkan wawancara adalah salah satu teknik pengumpulan data yang dilakukan dengan cara tanya jawab melalui tatap muka secara langsung dengan narasumber. Untuk dokumentasi adalah teknik pengumpulan data dengan cara melihat langsung data dari dokumen atau pun arsip-arsip terkait untuk mendukung kelengkapan data yang lain.

\section{Metode Analisis Data}

Data yang sudah didapatkan akan dianalisis dengan menggunakan metode kualitatif, kuantitatif, dan deskriptif. Metode kualitatif adalah metode riset yang bersifat deskriptif, menggunakan analisis, dan mengacu pada data. Metode kuantitatif adalah metode dengan menggunakan data numerik dan menekankan proses penelitian pada pengukuran hasil yang objektif. Metode deskriptif adalah metode yang digunakan dalam penelitian dengan cara penulis datang ke sumber data dan menganalisis data itu apa adanya. Data yang diperoleh ditabulasi kemudian dianalisis menggunakan metode perhitungan pada sistem produksi dan kelayakan usaha budidaya ikan lele (Clarias sp.). Variabel yang diamati pada sistem produksi adalah produktivitas dan kelulushidupan. Menurut Rohmana (2009) rumus menentukan produktivitas 
dan kelulushidupan adalah sebagai berikut:

\section{Produktivitas}

$$
\text { Produktivitas }=\frac{\mathrm{Wt}-\mathrm{W} 0}{\mathrm{~L}}
$$

Keterangan:

Wt : Biomassa akhir $(\mathrm{kg})$

W0 : Biomassa awal $(\mathrm{kg})$

L : Luas kolam $\left(\mathrm{m}^{2}\right)$

Kelulushidupan (SR)

$$
\mathrm{SR}=\frac{\mathrm{Nt}}{\mathrm{N} 0} \times 100 \%
$$

Keterangan:

SR : Kelulushidupan (\%)

N0 : Jumlah ikan awal tebar (ekor)

$\mathrm{Nt}$ : Jumlah ikan panen (ekor)

Variabel yang diamati pada kelayakan usaha diantaranya adalah Laba Rugi, R/C ratio, Break Even Point (BEP), dan Payback Period (PP).

\section{Laba atau Rugi}

Menurut Isamu, Salam, dan Yunus (2018), pendapatan usaha diperoleh dengan menggunakan persamaan sebagai berikut:

$$
\text { Laba atau Rugi= TR-TC }
$$

Keterangan:

TR: Total Revenue (Penerimaan Total

TC: Total Cost (Biaya Total)

\section{R/C Ratio}

Menurut Mahyudin (2010), cara menentukan $\mathrm{R} / \mathrm{C}$ ratio yaitu dengan menggunakan rumus sebagai berikut:

$$
\mathrm{R} / \mathrm{C} \text { ratio }=\frac{\mathrm{TR}}{\mathrm{TC}}
$$

Keterangan:
TR: Total Revenue (Penerimaan Total

TC: Total Cost (Biaya Total)

Break Even Point (BEP)

Menurut Sumardika (2013), Break Even Point (BEP) dapat dihitung berdasarkan rumus berikut:

$$
\text { BEP }(\text { unit })=\frac{\text { Biaya Tetap }}{\text { Harga Satuan }-\left(\frac{\text { Biaya Variabel }}{\text { Penjualan }}\right)}
$$

Payback Period (PP)

Menurut Mahyudin (2010), Payback Period (PP) dapat dihitung berdasarkan rumus sebagai berikut:

$$
\mathrm{PP}=\frac{\text { Total Investasi }}{\text { Laba Bersih }}
$$

\section{HASIL DAN PEMBAHASAN}

Hasil

Kinerja Teknis Budidaya Ikan Lele

Berikut merupakan grafik monitoring pertumbuhan ikan lele yang diidentifikasi selama satu bulan dapat dilihat pada Tabel 1 dan Gambar 1.

\section{Produksi}

Data produksi per siklus yang diperoleh dapat dilihat pada Tabel 2.

\section{Analisis Usaha}

Pada tabel 3 disampaikan tabel analisis usaha pembesaran ikan lele kelompok Mutiara. 
Tabel 1. Hasil penyortiran ikan lele

\begin{tabular}{lccc}
\hline No. & Panjang (cm) & Berat Rata-Rata (gr) & Jumlah (\%) \\
\hline 1. & $9-12$ & 16,3 & 58,4 \\
2. & $12-15$ & 28,6 & 41,6 \\
\hline
\end{tabular}

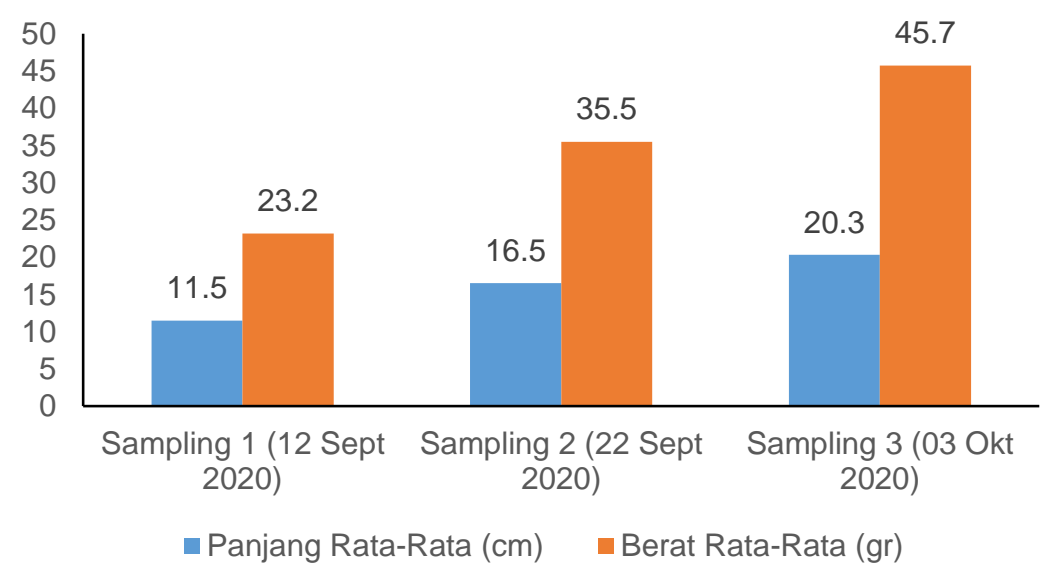

Gambar 1. Hasil sampling ikan lele dalam satu bulan

Tabel 2. Data hasil produksi selama dua siklus

\begin{tabular}{clccc}
\hline No & \multicolumn{1}{c}{ Parameter } & Siklus I & Siklus II & Rata-rata \\
\hline 1 & Luas Wadah $\left(\mathrm{m}^{2}\right)$ & 8 & 8 & 8 \\
2 & Penebaran Benih & & & \\
& Berat Rata-Rata (gr) & 0,65 & 0,65 & 1,5 \\
& Jumlah (ekor) & 8.000 & 10.000 & 9.000 \\
& Padat Tebar (ekor.m- $\left.{ }^{-2}\right)$ & 1.000 & 1.250 & 1.125 \\
3 & Panen & & & \\
& Bobot Rata-Rata(gr) & 100 & 100 & 100 \\
& Jumlah (ekor) & 7.000 & 9.500 & 8.000 \\
4 & Total Produksi (kg) & 700 & 950 & 825 \\
5 & SR (\%) & 90 & 95 & 92,5 \\
6 & Produktivitas (kg.m-2) & 87,5 & 118,7 & 102,9 \\
7 & Total Pakan (kg) & 700 & 900 & 825 \\
8 & FCR & 0,93 & 0,90 & 0,91 \\
\hline
\end{tabular}


Tabel 3. Analisis Usaha

\begin{tabular}{llr}
\hline No & Parameter Analisis Usaha & \multicolumn{1}{l}{ Nilai } \\
\hline 1. & Biaya Investasi (Rp) & 32.784 .500 \\
2. & Biaya Penyusutan (Rp) & 135.787 \\
3. & Biaya Tetap (Rp) & 477.656 \\
4. & Biaya Variabel (Rp.siklus $\left.{ }^{-1}\right)$ & 10.671 .250 \\
5. & Biaya Produksi (Rp.siklus $\left.{ }^{-1}\right)$ & 11.148 .906 \\
7. & Pendapatan (Rp.siklus $\left.{ }^{-1}\right)$ & 17.100 .000 \\
8. & Keuntungan (Rp.siklus $\left.{ }^{-1}\right)$ & 5.951 .094 \\
9. & ROI (\%) & 53,38 \\
10. & PP (bulan) & 16 \\
11. & BEP (Rp) & 1.273 .749 \\
12. & BEP (ekor) & 335 \\
13. & R/C & 1,53 \\
\hline
\end{tabular}

\section{Pembahasan}

\section{Profil Kelompok Tani Lele "Mutiara"}

Kelompok Tani Lele "Mutiara" berlokasi di Desa Kaligelang, Kecamatan Taman, Kabupaten Pemalang. Kelompok Tani Lele "Mutiara" merupakan kelompok pembudidaya ikan lele yang berdiri kurang lebih sudah 10 tahun yang lalu dan baru disahkan pada tahun 2019. Kelompok Tani Lele "Mutiara" didirikan oleh 3 orang yaitu Pak Nurrochim, Pak Kiswo, dan Pak Sudiyanto, dan kini sudah memiliki 20 anggota kelompok.

Umur merupakan salah satu faktor yang memengaruhi perilaku dalam melakukan pekerjaan secara optimal dan produktif. Menurut Undang-Undang No.mor 13 tahun 2003 Tentang Ketenagakerjaan, umur dapat dikategorikan menjadi: 1) produktif (15-64 tahun); 2) tidak produktif (< 15 tahun); 3) kurang produktif (>64 tahun). Rata-rata umur anggota Kelompok Tani Lele "Mutiara" adalah 3862 tahun. Hal ini menunjukkan bahwa anggota Kelompok Tani Lele "Mutiara" masuk dalam katagori umur produktif. Yani, Setijorini, dan Noviyanti (2010) mengemukakan bahwa jika 50\% anggota berusia dewasa pertengahan (usia 40-53 tahun), maka hal tersebut menunjukkan bahwa sebagian besar anggota kelompok berusia produktif dan mampu menjalankan aktivitas usaha tani, serta dapat berinteraksi dengan anggota kelompoknya

Selain umur, lama usaha juga dapat memengaruhi usaha pembudidaya. Pengalaman usaha pembudidaya ikan diklasifikasikan dalam kategori: 1) pengalaman baru adalah kurang dari 
10 tahun; 2) pengalaman sedang berkisar antara 10-20 tahun; 3) pengalaman lama lebih dari 20 tahun. Lama usaha rata-rata anggota Kelompok Tani Lele "Mutiara" kurang dari 10 tahun yaitu 4-9 tahun dan termasuk dalam katagori pengalaman yang masih baru, sehingga pembudidaya hanya mengikuti apa yang telah mereka lihat dari sesama pembudidaya ikan. Menurut Priyandika (2015), lamanya usaha seseorang dapat meningkatkan pengetahuannya dan akan berpengaruh pada tingkat pendapatannya. Semakin lama seseorang menekuni usahanya maka akan meningkat pula pengetahuan mengenai teknologi, perilaku pasar, dan modal dalam usaha yang dijalankannya.

\section{Sistem Budidaya Ikan Lele}

Sistem budidaya di Kelompok Tani Lele "Mutiara" merupakan sistem intensif. Hal ini karena wadah budidaya ikan lele pada Kelompok Tani Lele "Mutiara" sebagian besar adalah kolam bulat dan kolam tanah. Untuk teknologi yang digunakan cukup maju yaitu menggunakan teknologi bioflok. Selain itu kebutuhan pakan yang digunakan merupakan 100\% pakan buatan.

Intensifikasi budidaya ikan di tandai dengan peningkatan padat penebaran yang diikuti dengan peningkatan pemakaian pakan buatan kaya protein Rosmaniar (2011). Pada kolam budidaya ikan lele di Kelompok Tani Lele "Mutiara" memiliki padat tebar yang cukup tinggi yaitu 1000-1250 ekor.m². Selain itu, pakan yang digunakan juga memiliki kadar protein yang cukup tinggi yaitu $33 \%$. Budidaya ikan lele di Kelompok Tani Lele "Mutiara", menggunakan teknologi bioflok yaitu dengan melakukan larutan fermentasi yang berasal dari kapur, garam, molase, dan bakteri yang kemudian tumbuh plankton yang dapat dijadikan sumber makanan. Menurut Mulyadi (2011), Teknologi bioflok merupakan kumpulan (flok) algae, bakteria, protozoa dan partikel lain yang berupa bahan organik seperti fases dan sisa makan.

\section{Kinerja Teknis Budidaya Ikan Lele}

Usaha pembesaran ikan dilakukan di lahan masing-masing oleh anggota Kelompok Tani Lele "Mutiara". Berikut merupakan teknik dan tahapan pembesaran ikan lele yang dilakukan oleh Bapak Sukiswo (ketua kelompok):

\section{Persiapan Kolam}

Bapak Sukiswo memiliki delapan buah kolam untuk usaha pembesaran ikan lele, terdiri dari lima kolam terpal bundar dengan ukuran $4 \mathrm{~m}^{2}$ dan $2 \mathrm{~m}^{2}$, dan tiga kolam beton dengan ukuran $3 \times 3 \mathrm{~m}$. Persiapan kolam dimulai dengan pengurasan kolam, pembersihan dari lumut dan kotoran dengan menggunakan sikat 
dan waring. Kolam lalu dikeringkan selama kurang lebih 12 jam. Setelah dikeringkan, kolam diisi air baru dengan cara mengalirkan air dari sumur bor menggunakan pompa air. Ketinggian air yang digunakan dalam kolam yaitu $70-80 \mathrm{~cm}$. Setelah itu, ditambahkan larutan probiotik ke dalam air kolam. Untuk bak ukuran $4 \mathrm{~m}^{2}$ diberikan $500 \mathrm{ml}$ ramuan probiotik, 350 gram kapur tohor, 500 gram kapur dolomit, dan $3 \mathrm{~kg}$ garam. Kemudian air tersebut difermentasi selama 7-10 hari dengan tetap menyalakan aerasi.

Ramuan probiotik tersebut merupakan ramuan yang dibuat secara mandiri dengan bahan-bahan seperti telur, susu, yakult, pisang, nanas, molase, air kelapa, ragi, dan vitamin B. Salah satu bahan pembuatan probiotik alami adalah yakult dan molase. Yakult mengandung bakteri Lactobacillus sp. yang dapat mempercepat pertumbuhan ikan. Molase dapat dimanfaatkan oleh bakteri untuk menghasilkan protein. Hal ini sesuai dengan pendapat Mulyadi (2011) bahwa pemberian probiotik yang mengandung Lactobacillus sp. dan Bacillus sp. dapat meningkatkan pertumbuhan ikan lele dibandingkan ikan lele tanpa probiotik. Selain yakult, bahan probiotik alami lain yaitu molase yang dapat dimanfaatkan bakteri dengan baik sehingga dapat menghasilkan biomassa bakteri protein.

\section{Penebaran Benih}

Dalam satu kali siklus, benih yang ditebar sebanyak 8.000-10.000 ekor dengan ukuran $3-5 \mathrm{~cm}$. Benih yang ditebar biasanya diperoleh dari para pembudidaya pembenihan ikan lele di Kabupaten Pemalang yaitu di Desa Petarukan, Pegundan, dan Nyamplung Sari, dan di luar Kabupaten Pemalang yaitu dari Tegal. Sebelum benih ditebar, benih diamati kelincahan dan keadan fisiknya untuk mengetahui kesehatan benih. Menurut Rosmaniar (2011), ciriciri benih yang sehat adalah gerakannya lincah, tidak terdapat cacat atau luka dipermukaan tubuhnya, bebas dari bibit penyakit dan gerakan renangnya normal.

\section{Pemeliharaan ikan lele}

Pakan yang diberikan selama pemeliharaan ikan lele adalah pakan buatan dengan kadar protein yang cukup tinggi yaitu $33 \%$. Ukuran pakan yang digunakan berbeda tergantung umur pemeliharaan. Pemberian pakan dilakukan tiga kali sehari yaitu pada pagi (08.00-09.00 WIB), sore (16.00-17.00 WIB), dan malam hari (22.00-23.00) WIB. Sebelum pakan diberikan, pakan difermentasi terlebih dahulu. Sebanyak $50 \mathrm{ml}$ probiotik dicampurkan ke delam 1 kg pakan dan dicampur air sebanyak 300 ml. Pakan dimasukkan dalam ember dan didiamkan terlebih dahulu selama 1-5 jam. Tujuan fermentasi pakan yaitu untuk 
memotong rantai peptida protein dari rantai yang panjang menjadi pendekpendek. Bakteri akan memanfaatkan substrat yang ada di dalam pakan kemudian diubah menjadi protein yang lebih baik. Selain itu, fermentasi dilakukan agar pakan dapat dicerna dengan baik oleh ikan karena pakan yang telah difermentasi sifatnya lebih lunak (Mulyadi 2011).

Pada awal penebaran benih, pakan diberikan 3 kali sehari, dengan jumlah 3$5 \%$ dari total biomassa ikan. Semakin lama pemeliharaan jumlah pemberian pakan (FR) semakin menurun. Jumlah pakan untuk ikan lele berumur dua bulan ke atas $(>12 \mathrm{~cm})$ adalah $2 \%-3 \%$ dari total biomassa ikan. Namun demikian, pemberian pakan perlu mempertimbangkan nafsu makan ikan. Jika ikan lele gerakannya sudah mulai lambat dan tidak aktif pada saat pemberian pakan, maka nafsu makan ikan lele sudah berkurang. Menurut Murhananto (2002) ikan lele yang berumur 10 hari diberikan pakan 4\%-5\% dan ikan lele yang berumur 60 hari diberikan pakan $2 \%$ dari biomassanya.

\section{Penyortiran (Grading)}

Ikan lele merupakan ikan yang kanibal yaitu dapat memakan sesamanya sehingga selama pemeliharaan ikan harus dilakukan penyortiran. Penyortiran merupakan kegiatan pemisahan antara ikan yang berukuran besar dengan ikan yang berukuran kecil. Penyortiran biasanya dilakukan setiap tiga minggu sekali, dengan melihat kondisi ikan lele, jika ukurannya sudah tidak seragam maka penyortiran dapat dipercepat. Penyortiran dilakukan pada sore hari. Alat-alat yang digunakan antara lain ember grading sesuai ukuran yang diinginkan, jaring, timbangan, dan ember. Penyortiran dilakukan dengan cara mengurangi air pada kolam dan menyiapkan kolam yang akan digunakan untuk pemisahan ikan lele. Setelah air sudah terkuras, ikan dijaring dan dimasukkan pada ember grading.

Saat berumur 56 hari, terdapat sekitar 5.000 ekor ikan yang disortir. Ember grading yang digunakan yaitu ember dengan ukuran 9-12 dan 12-15. Hasil penyortiran dapat dilihat pada Tabel 1 .

Dari data hasil penyortiran tersebut terlihat bahwa sebagian besar $(58,4 \%)$ ikan lele yang dipelihara selama 56 hari memiliki berat rata-rata 16,3 gram. Hal ini sesuai dengan pendapat Suprapto dan Samtafsir (2013), bahwa ikan lele yang berumur 50-60 hari berat rata-ratanya adalah 5-20 gram dan panjang rataratanya $9-12 \mathrm{~cm}$.

Sampling

Sampling merupakan kegiatan pengukuran berat dan panjang ikan untuk mengetahui pertumbuhan dan perkembangan ikan. Sampling biasanya dilakukan setiap 10 hari sekali. Pada saat 
sampling, sebanyak 0,5\% dari jumlah ikan atau sekitar 50 ikan diambil kemudian ditimbang. Selain berat ikan, pada saat sampling juga dilakukan pengukuran panjang ikan dengan menggunakan penggaris.

Pertumbuhan dan perkembangan ikan, biasanya dipengaruhi oleh kualitas air, benih, maupun pakan. Pertumbuhan ikan lele yang dipelihara oleh kelompok "Mutiara", tergolong lambat. Hal ini diduga karena pakan yang diberikan berasal dari merek yang berbeda dengan biasanya. Selain pakan, penyebab lainnya diduga akibat padat tebar ikan lele yang dinaikkan menjadi 1.250 ekor.m-2 dari sebelumnya 1.000 ekor.m-2. Nurlaela, Tahapari, dan Sularto (2010) menyatakan bahwa perbedaan padat tebar 5-20 ekor.m-2 dapat menyebabkan pertumbuhan semakin menurun, karena terjadi persaingan baik ruang gerak, oksigen terlarut maupun pakan. Hal ini sesuai dengan pendapat Handajani dan Hastuti (2002) yang menyatakan bahwa semakin tinggi kepadatan ikan maka akan memengaruhi tingkah laku dan fisiologi ikan terhadap ruang gerak yang menyebabkan ikan stres. Selain itu, pertumbuhan, pemanfaatan makanan dan kelulushidupan juga mengalami penurunan. Stres yang muncul akibat dari padat penebaran yang semakin tinggi meningkatkan energi pemeliharaan, hal tersebut akan mengurangi energi yang seharusnya diperlukan untuk pertumbuhan (Abidin 2009).

\section{Pengelolaan Kualitas Air}

Pengukuran dan pengelolaan kualitas air merupakan salah satu kegiatan pada tahap pemeliharaan ikan yang harus diperhatikan. Parameter kualitas air seperti suhu, $\mathrm{pH}, \mathrm{DO}, \mathrm{NH}_{3}$, dan $\mathrm{NH}_{4}$ sebaiknya diukur secara berkala agar kualitas air dapat terkontrol. Namun, karena adanya keterbatasan alat, anggota kelompok melakukan pengontrolan kualitas air dengan mengamati keadaan air. Air yang kurang baik biasanya ditandai dengan bau amis, berbusa, berwarna warna coklat keputihan atau pucat.

Untuk menjaga kualitas air biasanya anggota kelompok menggunakan ramuan untuk air. Ramuan tersebut biasanya diberikan lima hari sekali dengan dosis $500 \mathrm{ml}$ untuk kolam ukuran $4 \mathrm{~m}^{2}$. Bahan-bahan pembuatan ramuan tersebut adalah jahe, kunyit temulawak, molase, gula merah, pisang, susu, dan probiotik. Selain itu, pengelolaan kualitas air juga dilakukan dengan membuang sebagian volume air yang memiliki kadar amoniak sudah terlalu tinggi kemudian diganti dengan air baru. Cara lainnya menggunakan ekstrak daun pepaya kemudian dicampur dengan garam dan probiotik berupa booster aquaenzyms yang diberikan pada air pemeliharaan. Probiotik ini 
dapat menguraikan sisa pakan dan meningkatkan kualitas air.

Keterbatasan alat ukur kualitas air, pada penelitian ini hanya mengukur $\mathrm{pH}$, dan suhu air. Pengukuran $\mathrm{pH}$ dan suhu air dilakukan satu minggu sekali. Suhu air diukur dengan menggunakan termometer, dan $\mathrm{pH}$ diukur dengan menggunakan $\mathrm{pH}$ meter. Suhu air pada semua kolam adalah antara $27-30^{\circ} \mathrm{C}$, dan $\mathrm{pH}$ pada semua kolam adalah antara 7,27,6. Menurut Nisrinah, Subandiyono, dan Elfitasari (2013), suhu optimal untuk pertumbuhan ikan lele (Clarias sp.) yaitu $25-30^{\circ} \mathrm{C}$ dan $\mathrm{pH}$ optimal untuk budidaya ikan lele (Clarias sp.) adalah 7-8,5. Jika nilai $\mathrm{pH} \mathrm{9,} \mathrm{dapat} \mathrm{menyebabkan} \mathrm{berku-}$ rangnya nafsu makan pada ikan lele (Clarias sp.).

\section{Pengendalian Hama dan Penyakit}

Dalam budidaya ikan, hama dan penyakit ikan merupakan kendala utama sehingga perlu dilakukan pencegahan maupun pengendalian agar ikan dapat terhindar dari hama dan penyakit. Upaya pengendalian hama yang dilakukan adalah dengan memasang biosecurity berupa pagar dari baja ringan pada sekitar kolam. Pemasangan biosecurity tersebut dilakukan agar ikan lele dapat terhindar dari hama seperti ayam, kucing, dan lainlain.

Penyakit yang biasa terjadi pada ikan lele yaitu penyakit kuning, jamur kulit, sirip merah dan biasanya dari virus. Pencegahan dan pengendalian penyakit yang dilakukan adalah membuat obat yang dibuat dari bahan-bahan alami. Pencegahan lain yang dilakukan yaitu dengan melakukan pengendalian kualitas air dengan memberikan ramuan alami setiap lima hari sekali. Obat alami yang diberikan untuk mencegah penyakit dari jamur adalah lengkuas. Sedangkan pencegahan penyakit dari virus dilakukan menggunakan bawang putih dan daun sirih. Selain menggunakan obat dari bahan alami, anggota kelompok juga menggunakan obat komersial salah satunya adalah everlac. Everlac merupakan obat yang digunakan untuk meningkatkan sistem kekebalan. Everlac memiliki kandungan bakteri Lactobacillus sp. yang bermanfaat untuk memperbaiki mikroflora dalam pencernaan ikan sehingga dapat meningkatkan sistem kekebalan dalam tubuh ikan. Everlac biasanya dicampurkan pada air kolam dengan dosis 7-10 gram.m².

\section{Pemanenan}

Pemanenan merupakan tahap terakhir dalam budidaya ikan lele Pada usaha pembesaran ikan lele, pemanenan biasanya dikerjakan pada sore hari dan dilakukan secara parsial yaitu setiap 2,5 bulan, 3 bulan, dan 3,5 bulan dengan tetap melihat ukuran dan berat ikan lele agar layak konsumsi. 
Rata-rata bobot ikan yang dipanen panen adalah 100 gr.ekor $^{-1}$. Nilai kelulushidupan (SR) usaha pembesarkan ikan ini adalah 92,5\%. Hal ini menunjukkan bahwa tingkat kelangsungan hidup ikan lele pada usaha budidaya ikan lele ini cukup bagus. Menurut SNI 6484.3: 2014, bobot panen ikan adalah antara 100150 gr.ekor $^{-1}$ dengan tingkat kelangsungan hidup $80 \%$. FCR usaha pembeseran ikan lele yang diperoleh adalah 0,91, dengan kata lain $1 \mathrm{~kg}$ daging ikan lele dihasilkan dari pemberian pakan sebanyak 0,91 kg. FCR 0,91 dapat dikategorikan efisien karena dalam pemeliharaan menggunakan teknologi bioflok sehingga nilai FCR dapat diturunkan. Sesuai pendapat dari Widanarni, Wahjuningrum, dan Setiawati (2009) yang menyatakan bahwa aplikasi teknologi bioflok dapat menurunkan nilai FCR karena adanya peningkatan biomassa mikroba bioflok sebagai sumber nutrisi atau makanan tambahan untuk ikan lele.

\section{Pemasaran}

Model pemasaran yang dilakukan Kelompok Tani Lele "Mutiara" saat ini dengan cara melakukan kerja sama dengan distributor/tengkulak, ataupun langsung kepada konsumen. Biasanya dari kelompok menghubungi tengkulak bahwa ada ikan lele yang siap dipanen, setelah itu tengkulak pada sorenya datang untuk mengikuti proses pemanenan hingga pengangkutan. Setelah itu, pedagang, pengumpul menjual ikan lele langsung kepada konsumen, pasar, warung, restoran, dan sebagainya. Pada hari-hari besar, konsumen membeli ikan lele langsung ke tempat pembudidaya, tanpa melalui perantara. Area pemasaran ikan lele kelompok ini adalah Pemalang, Tegal, dan Bekasi.

\section{Analisis Usaha dan Kelayakan Usaha \\ Menurut Rahardi, Regina, dan Na-} zaruddin (2008) analisis usaha dalam bidang perikanan merupakan pemeriksaan keuangan untuk mengetahui sampai di mana keberhasilan yang telah dicapai selama usaha perikanan itu berlangsung. Dengan analisis usaha ini, pengusaha membuat perhitungan dan menentukan tindakan untuk memperbaiki dan meningkatkan keuntungan dalam usahanya.

Dari data analisis usaha di atas dapat dihitung kelayakan usahanya. Perhitungan ini bertujuan untuk meningkatkan efisiensi dalam mengelola usaha budidaya ikan lele yang dilakukan. Dengan keuntungan yang diperoleh dalam satu siklus, usaha pembesaran ikan lele dapat mengembalikan modal biaya produksi sebesar 53,37\% dari biaya produksi yang telah dikeluarkan. Payback Periode (PP) 16 bulan artinya, lamanya total investasi dapat dikembalikan dari keuntungan yang diperoleh dalam waktu 16 
bulan atau 1 tahun 2 bulan. Sehingga investasi usaha pembesaran dapat dikembalikan setelah 5 kali produksi. Untuk mencapai titik impas hasil penjualan minimal sebesar Rp. 1.273.749 dengan jumlah unit minimum yang harus diproduksi yaitu $33,5 \mathrm{~kg}$ dengan harga benih di pasaran yaitu Rp. 18.000 per kg. Nilai $R / C$ ratio $>1$ menunjukkan bahwa pendapatan sebesar Rp. 5.700.000 lebih besar dari total biaya operasional yaitu Rp. 3.557.083 sehingga usaha ini layak untuk dijalankan, karena dengan biaya produksi Rp. 3.716.302 diperoleh keuntungan sebesar Rp. 1.983 .698 setiap bulannya.

\section{SIMPULAN}

Hasil dari penelitian di Kelompok Tani Lele "Mutiara" Desa Kaligelang, Kecamatan Taman, Kabupaten Pemalang adalah sebagai berikut:

1. Kelompok Tani Lele "Mutiara" melakukan usaha pembesaran dengan menggunakan teknologi bioflok. Tahapan produksi ikan lele meliputi persiapan kolam, penebaran benih, pemberian pakan, pengelolaan kualitas dan pemanenan. Padat tebar rata-rata dalam budidaya ikan lele adalah 1.000-1.250 ekor. $\mathrm{m}^{-2}$ berhasil di panen sebanyak $825 \mathrm{~kg}$ ikan lele dengan SR 92,5\%, produktivitas kolam 102,9 kg.m-2 dan FCR sebesar 0,91 .
2. Pembesaran ikan lele layak dijadikan usaha. Dengan keuntungan $\mathrm{Rp}$. 5.951 .094 dengan biaya produksi Rp. 11.148.906 per siklus. Hasil analisis usaha BEP 33,5 kg PP 1,4 tahun, ROI 53,37\%, dan R/C Rasio 1,53.

\section{PERSANTUNAN}

Kami menyampaikan ucapan terima kasih kepada pihak-pihak yang mendukung dalam penulisan naskah ini. Khususnya kepada narasumber utama, yaitu Bapak Sukiswo selaku ketua kelompok dan semua anggota Kelompok Tani Lele "Mutiara".

\section{DAFTAR PUSTAKA}

Abidin, Zainal. 2009. "Kinerja produksi benih gurami osphronemus gouramy lac ukuran $8 \mathrm{~cm}$ dengan padat penebaran 3,6 dan 9 ekor/liter pada sistem resirkulasi [Skripsi]." Institut Pertanian Bogor.

Anon. 2020. 'Kelompok Tani 'Mutiara' Desa Kaligelang Panen Perdana Lele." Diambil 23 Oktober 2020 (https://www.pemalangkab.go.id/20 20/06/kelompok-tani-mutiara-desakaligelang-panen-perdana-lele/).

BPS. 2016. Produksi Perikanan Budidaya Menurut Kabupaten/Kota dan Subsektor di Provinsi Jawa Tengah. Semarang (ID): Badan Pusat Statistik Provinsi Jawa Tengah. 
DJPB. 2018. "Subsektor Perikanan Budidaya Sepanjang Tahun 2017 Menunjukkan Kinerja Positif." Diambil 22 Desember 2020 (https://kkp.go.id/djpb/artikel/3113subsektor-perikanan-budidayasepanjang-tahun-2017menunjukkan-kinerja-positif).

Handajani, Hany, dan Sri Dwi Hastuti. 2002. Budidaya perairan. Malang (ID): Bayumedia.

Isamu, Imelda, Idrus Salam, dan Lukman Yunus. 2018. "Analisis Kelayakan Usaha Udang Vaname Pola Tradisional Plus di Kecamatan Samaturu Kabupaten Kolaka." Jurnal Sosio Agribisnis 3(1). doi: 10.33772/jsa.v3i1.7400.

Mahyuddin, Kholis. 2010. Panduan Lengkap Agribisnis Lele. Jakarta (ID): Penebar Swadaya.

Mulyadi, Anggie Ekawati. 2011. "Pengaruh pemberian probiotik pada pakan komersil terhadap laju pertumbuhan benih ikan patin siam (Pangasius hypophthalamus) [Skripsi]." Universitas Padjadjaran.

Murhananto. 2002. Pembesaran Lele Dumbo di Pekarangan. diedit oleh Mulyono. Jakarta (ID): Agromedia Pustaka.

Nisrinah, Subandiyono, dan Tita Elfitasari. 2013. "Pengaruh penggunaan bromelin terhadap tingkat pemanfaatan protein pakan dan pertumbuhan lele dumbo (Clarias gariepinus)." Journal of Aquaculture Management and Technology 1(2):57-63.

Nurlaela, Ika, Evi Tahapari, dan Sularto Sularto. 2010. "Pertumbuhan ikan patin nasutus (Pangasius nasutus) pada padat tebar yang berbeda." Hal. 31-36 in Prosiding Forum Inovasi Teknologi Akuakultur.

Priyandika, Akhbar Nurseta. 2015. "Analisis Pengaruh Jarak, Lama Usaha, Modal, Dan Jam Kerja Terhadap Pendapatan Pedagang Kaki Limakonveksi (Studi Kasus Di Kelurahan Purwodinatan Kota Semarang) [Skripsi]." Universitas Diponegoro.

Rahardi, Floribertus, Nazaruddin, dan Regina Kristiawati. 2008. Agribisnis Perikanan. Jakarta (ID): Penebar Swadaya.

Rohmana, Dasu. 2009. "Konversi limbah budidaya ikan lele, Clarias sp. menjadi biomassa bakteri heterotrof untuk perbaikan kualitas air dan makanan udang galah, Macrobrachium rosenbergii [Tesis]." Institut Pertanian Bogor.

Rosmaniar. 2011. "Dinamika Biomassa Bakteri dan Kadar Limbah Nitrogen pada Budidaya Ikan Lele Dumbo (Clarias gariepinus) Intensif Sistem 
Heterotrofik [Skripsi]." Universitas Islam Negeri Syarif Hidayatullah.

Sumardika, Putu. 2013. Kewirausahaan

Perikanan. Jakarta (ID): Bina Sumberdaya MIPA.

Suprapto, dan Legisan S. Samtafsir. 2013. Biofloc-165: rahasia sukses teknologi budidaya lele. Depok (ID): Agro 165.

Undang-Undang Nomor 13. 2003. tentang Ketenagakerjaan. Indonesia.
Widanarni, Dinamella Wahjuningrum, dan Mia Setiawati. 2009. Optimasi Budidaya Super-Intensif Ikan Nila Ramah Lingkungan: Dinamika Mikroba Bioflok. Bogor (ID).

Yani, Diarsi Eka, Ludivica E.S, dan Rinda Noviyanti. 2010. "Presepsi Anggota Terhadap Peran Kelompok Tani Dalam Meningkatkan Kemampuan Penguasaan Teknologi Budidaya Belimbing." Matematika, Sains, dan Teknologi (JMST) 11(2):133-45. 